\title{
KÉZIKÖNYV AZ INTERNETES KOMMUNIKÁCIÓ ÉS MÉDIA KOMPLEX VILÁGÁRÓL
}

Mit jelent az online kifejezés? Egymással hálózatba kötött számítógépeket? Az időtől-tértől függetlenül elérhető tartalmat? A hálózaton keresztül kommunikáló felhasználókat? Mindez (és számtalan további elem) együttesen tartozik az 'online' fogalmához, de ma már kevésbé az egyes komponensek, sokkal inkább az online létezésmód által előidézett gyökeres változások érdemesek a figyelemre. Lassan közhelyszámba megy minden olyan megállapítás, amely a világháló működése kapcsán próbálja leírni, megértetni, milyen alapvető változásokat generál az online lét a társadalom és a gazdaság mélyszerkezetére, a virtuális világban kialakuló digitális identitás az egyes individuumokra, az omniprezens hálózati jelenlét a társas kapcsolatok alakulására - és a sor vég nélkül folytatható.

Szüts Zoltán Online címü, 2018 végén megjelent kézikönyvéből rengeteg információhoz lehet hozzájutni arról, hogy a három fő összetevő - az eszközök, a tartalom és a felhasználók - együtteséből az utóbbi évtizedekben hányféle kommunikációs forma és jelenség alakult ki az interneten. Az első és talán legfontosabb állítás: az emberiség történelme során mindeddig egyetlen kommunikációs módozat vagy médium sem épült be ilyen erővel a társadalom, a gazdaság és a kultúra alrendszereibe.

Az online kommunikáció és média kutatására az utóbbi másfél-két évtizedben egy önálló diszciplína, az internettudomány alakult ki, amely a számítástechnika, az informatika és a mérnöki tudományok eredményei mellett a politikai, gazdasági, kulturális, pszichológiai és egyéb társadalmi tényezőket veszi górcső alá. A szerző idézi William H. Duttont, aki szerint az internettudomány „megjelenése azon elméleti és kutatási kérdésekre helyezi a hangsúlyt, melyek az internet, a világháló és a kapcsolódó információs és kommunikációs technológiák széles körű elterjedésének és változatos felhasználásának kulturális implikációira vonatkoznak".

Az ismert médiakutató az internettudományon belül az online kommunikáció és média rendkívül összetett, folyamatosan változó, bővülő világának, illetve a technológiai megoldások mérföldköveinek bemutatása mellett a világhálón elérhető közlési formák, valamint a föbb tartalomtípusok történetét és elméletét tárgyalja, az online tartalom létrehozását és továbbítását, a kódolást és a dekódolást, továbbá az információfeldolgozást és -megőrzést állítva a középpontba.

Szerzőnk a hat-hét évtizedet felölelő fenoména, a számítógépekkel zajló kommunikáció technika- és társadalomtörténetének leírására a kronologikus elbeszé- 
lésmódot választotta, törekedve a bonyolult jelenségek közötti összefüggések, illetve a hálózati média és kommunikáció által a társadalmi-kulturális viszonyokra gyakorolt kölcsönhatások feltárására.

Az öt fö részre és ötvennégy fejezetre tagozódó, közel ötszáz oldalas kötetben jelentős helyet kap a világháló múködésének kitalálásában, kimunkálásában fontos szerepet játszó elméleti és gyakorlati szakemberek eredményeinek bemutatása.

Az alapozónak tekinthető első - a könyvben nulladiknak nevezett - részegység röviden érinti a hálózattudomány kialakulását, majd leírja a hagyományos és a modern kommunikációs hálózatok történetét, a vezetékes, illetve a vezeték nélküli internetkapcsolatok főbb ismérveit. Az ezt követő fejezet már nemcsak a számítógépek fejlesztésének történetével, de az általuk kiváltott társadalmi, kulturális hatásokkal is foglalkozik. A számítógépek történeti fejlödésének utolsó állomása a korábbi komputerek kapacitását sokszorosan meghaladó, hordozható számítógépként funkcionáló okostelefonok színre lépése.

A második nagy rész a hálózatok kialakulását ismerteti, egészen az internet - a szerző által parafrazeált kifejezéssel „szép új világháló” - széles körü elterjedéséig, vagyis annak a mindennapjainkban tapasztalható jelenségnek az általánossá válásáig, amelynek következtében az online hálózatok valamennyi „emberi aktivitás domináns formájává" és színterévé váltak. Az olvasó megismerheti a mindmáig érvényes doménnévrendszer születésének idejét - ki gondolná, hogy ezek az azonosítók kis híján ötven éve szolgálják a világháló használóit? Az internetet az „őskor” óta ismerők is felkaphatják a fejüket az „információs szupersztráda” építéséröl szóló fejezet olvastán: már több mint három évtized eltelt azóta, hogy az USA akkori alelnöke, Al Gore nagysebességü, szélessávú hálózatok kiépítését javasolta.

A világháló címủ részegységben a ma ismert internetig jutunk el. A fö téma itt a Tim Berners-Lee által kigondolt, és 2019. március 12-én a 30. születésnapját ünneplö World Wide Web, amelyre szerzőnk leggyakrabban a világháló elnevezést használja. A bevezetés címe: A felhasználók felemelkedése felér egy dramaturgiai felütéssel; és valóban, itt érünk el az online kommunikáció paradigmaváltó társadalmi, kulturális hatásainak megismeréséig. A web atyjaként tisztelt Berners-Lee zseniális meglátással szervezte egységes rendszerbe a számítógépeket hálózatba kötő technológiát, a tartalmak egymáshoz társítását lehetővé tevő hipertextet, illetve a mindezt kezelni képes webböngésző programokat - mindezzel forradalmi változást indítva el. (Más kérdés, hogy a 30. évforduló kapcsán az azóta lovaggá ütött kutató azt nyilatkozta, hogy álmaiban az internetet sokkal jobbnak képzelte el, mint amilyenné az utóbbi években vált...)

A világhálót taglaló rész az internetes kommunikáció formáinak és típusainak kialakulását, fejlődését tekinti át. A szerző emléket állít az elméleti alapokat lefektető tudósoknak, majd ismerteti a világháló nyelvét: a hipertextet, majd visszatekint a webböngészők versengésére, és bemutatja a nyilvánosság 
virtuális tereit: a fórumokat, a blogokat, továbbá az újmédia körébe sorolható egyéb jelenségeket, végül kitér az új típusú online közösségek kialakulására, az MP3 által generált zenei „forradalomra”, a képek előretörése által előidézett másodlagos írásbeliségre.

Vélhetően a szerző és a recenzens közötti generációs különbség okán tűnt föl, hogy az interaktivitásra szánt rövidke alfejezet mennyire mást jelent most, mint amit e fogalom alatt az „ősidőkben”, a személyi számítógépek elterjedésének idején értettek. Szűts Zoltán csak a virtuális valóság kapcsán, szinte mellesleg említi az interaktivitást, amely az 1990-es években a webböngészők által lehetővé tett kétoldalú kommunikáció (egyik) legfőbb előnyeként vonult be a köztudatba, azáltal, hogy passzív fogyasztókból aktív résztvevőkké léptette elő az internethasználókat.

A web 2.0 és a közösségi média címet viselö nagy egység első fejezete: A prosumerek születése - folytatva a kronológiai tárgyalásmódot - a 2004 utáni időszak legfontosabb jelenségegyüttesére fókuszál, amely a maga teljességében ma még nem felbecsülhető társadalmi-kulturális-gazdasági változásokat indukált. Jó angol szokás szerint a prosumer kifejezés két szó összevonásából (producer + consumer) keletkezett, és találóan fejezi ki az online médiához füződő új viszonyt, amelyben a felhasználók nagy többsége már nemcsak tartalomfogyasztói, de -létrehozói szerepet is betölt. Ha a közösségi oldalakra feliratkozott több milliárdnyi felhasználó által generált, irdatlan mennyiségủ online tartalomra gondolunk, akkor válik érthetővé, miért tekintik a médiakutatók paradigmatikus erejűnek a „webkettő” által előidézett társadalmi-kulturális változásokat.

A záró rész megkísérli a jelen és a jövő kihívásaival való szembenézést - és a kísérletet itt azért hangsúlyozzuk, mert a jelenleg széles körben tapasztalt jelenségek valós társadalomformáló hatásaival korántsem vagyunk, mert egyelöre nem is lehetünk tisztában. Napjainkban még nem lehet tudni, milyen technológiai változások fogják az elkövetkező évtizedekben makro-, mezo- és mikroszinten - vagyis társadalmi, intézményi és egyéni szinten - megváltoztatni az emberi létet.

Az Online címü kötet a Wolters Kluwer kiadó médiatudományi sorozatának tagjaként látott napvilágot, és - akárcsak a tematikus sorozat többi tagjából - ebből is fájóan hiányzik a tárgyalt téma bibliográfiája. A kiadó annak ellenére nem járul hozzá, hogy a (jegyzetekkel kevert) lapalji szakirodalmi hivatkozásokból a kézikönyvek iránti elvárásoknak megfelelő bibliográfia készüljön, hogy a sorozatba tartozó kötetek recenzensei korábban már szóvá tették a felhasznált irodalom áttekinthető jegyzékének hiányát.

Az imponáló mennyiségủ tudáselem felsorakoztatása mellett a kötet egyik nagy erénye, hogy elfogulatlan tárgyilagossággal mutatja be az online lét által előidézett társadalmi-kulturális változásokat, valamint annak - akár pozitívnak, akár negatívnak minősíthető - hatásait. Szüts Zoltánnak sikerült a maga elé ki- 
tủzött célt elérnie: a magyar nyelvủ kommunikáció- és médiatudomány területén hiánypótló, összefoglaló munkát tett le az asztalra, amely nemcsak a téma iránt érdeklődők számára jelent értékes támpontot az internet jelenségei közötti eligazodásban, de az egyetemi oktatás számára is kiváló segítséget jelent.

(Szüts Zoltán: Online - Az internetes kommunikáció és média története, elmélete és jelenségei. Budapest: Wolters Kluwer, 2018, 488 o.)

Tószegi Zsuzsanna

c. egyetemi docens

Eötvös Loránd Tudományegyetem Bölcsészettudományi Kar Könyvtár- és Információtudományi Intézet 